\title{
FORWARD PREMIA IN ELECTRICITY MARKETS: TWO CAVEATS
}

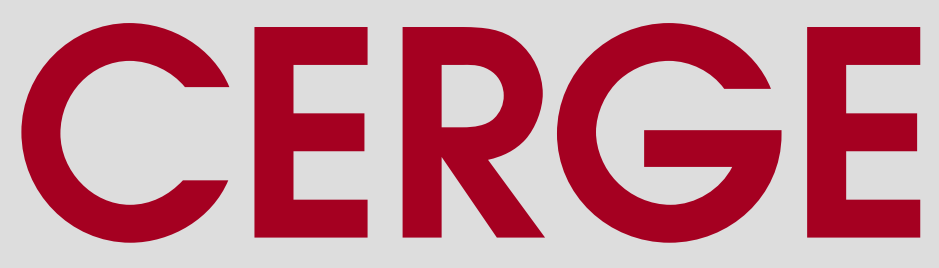




\section{Working Paper Series 543 (ISSN 1211-3298)}

\section{Forward Premia in Electricity Markets: Two Caveats}

Silvester van Koten

CERGE-EI

Prague, June 2015 
ISBN 978-80-7343-348-2 (Univerzita Karlova. Centrum pro ekonomický výzkum a doktorské studium)

ISBN 978-80-7344-340-5 (Akademie věd České republiky. Národohospodářský ústav) 


\title{
Forward Premia in Electricity Markets: Two caveats"
}

\author{
SILVESTER VAN KOTEN** \\ University of Economics (V̌́E) \\ CERGE-EI, a joint workplace of Charles University in Prague and the \\ Economics Institute of the Academy of Sciences of the Czech Republic
}

\begin{abstract}
Two important caveats are made for applications and empirical tests of Bessembinder and Lemmon's (2002) theoretical risk premium model for forward premia. Firstly, (relative) forward premia (eventually) decrease in mean power demand. Secondly, empirical tests should use a definition of mean power demand in line with Bessembinder and Lemmon's (2002) theory to avoid confounds.
\end{abstract}

\begin{abstract}
ABSTRAKT
Dvě důležitá upozornění jsou uvedena pro aplikaci a empirické testování teoretického modelu rizikové prémie Bessembinder a Lemmon (2002) pro forwardové prémie. Za prvé (relativní) forwardové prémie mohou prrípadně klesat v průměrné poptávce po elektřině. Za druhé empirické testy by měly používat definici průměrné poptávky po elektřině v souladu s teorií Bessembinder a Lemmon (2002), aby bylo možné vyhnout se nejasnostem.
\end{abstract}

Key words: $\quad$ Forward Premia, Electricity Markets, Energy Economics, Mean Power Demand, Financial Markets

JEL Classification: G13, G17, L94, Q41

\footnotetext{
${ }^{*}$ I thank Andreas Ortmann, Sergey Slobodyan, and Michal Zator for their helpful comments. Special thanks to Henrik Bessembinder and Michael Lemmon for their detailed and generous comments on earlier drafts. I also thank my research assistant Marek Zelenay for his excellent research support. All errors remaining in this text are the responsibility of the author. Financial support from research grant GA15-03488S from the Czech Science Foundation (GAČR) and the PRE Corporate Chair is gratefully acknowledged.

${ }^{* *}$ The University of Economics (VŠE), Department of Institutional, Environmental and Experimental Economics, Churchill Square 4, 13000 Prague, Czech Republic; CERGE-EI, a joint workplace of Charles University in Prague and the Economics Institute of the Academy of Sciences of the Czech Republic, Politických vězňů 7, 11121 Prague, Czech Republic. Fax: +420 224005 333. Email: silvester.vankoten@cerge-ei.cz and silvester.vankoten@vse.cz.
} 


\section{Introduction}

Bessembinder and Lemmon (2002) formulate an influential ${ }^{1}$ risk premium theory, linking the forward electricity price to the expected spot electricity price. The theory and its predictions are of prime importance for participants in electricity markets as electricity spot prices, due to the near impossibility to store electricity, show extreme volume and price volatility. The price volatility of electricity can be two orders of magnitude higher than for other commodities or financial instruments (Weron, 2006). In addition, whereas in the past they were sheltered from risk by the model of vertically integrated utilities operated as regulated (state) monopolies, in the present liberalized model of unbundling and competition, electricity producers must shoulder the large risks of volatility themselves. Indeed, as a result of the increase in risk, trading in derivatives has been increasing. ${ }^{2}$

However, two important caveats are made for applications and empirical tests of Bessembinder and Lemmon's (2002). The first caveat regards the theory: Bessembinder and Lemmon (2002) state that forward premia and relative forward premia increase in mean power demand. Simulations show that, while (relative) forward premia initially increase in mean power demand, they eventually decrease. This seems to have practical relevance especially for relative forward premia. The second caveat regards the empirical strategy employed to test the aforementioned hypothesis. In empirical tests (Bessembinder and Lemmon, 2002; Karakatsani and Bunn, 2005; Lucia and Torro, 2008; Furio and Meneu, 2009; Handika and Trück, 2013), the hypothesis is tested by regressing the forward premium on the monthly mean power demand. Mean power demand as used in Bessembinder and Lemmon (2002), however, is an average over the period for which the retail rate is fixed. Averaging the mean demand over a shorter

\footnotetext{
${ }^{1}$ Bessembinder and Lemmon (2002) has been cited 506 times according to Google Scholar, 155 times according to the Web of Science and 208 times according to Scopus (accessed on 4 March 2015). The theory and the four hypotheses derived from the theory have been used extensively in publications and studies of electricity price data. See, for example, Longstaff and Wang (2004), Karakatsani and Bunn (2005), Diko, Lawford, and Limpens (2006), Hadsell and Shawky (2006), Douglas and Popova (2008), Lucia and Torro (2008), Weron (2008), Daskalakis and Markellos (2009), Redl, Haas, Huber, and Böhm (2009), Botterud, Kristiansen, and Ilic (2010), Furio and Meneu (2010), Haugom and Ullrich, (2012), Bun and Chen (2013), Handika and Trück (2013), Redl and Bunn (2013), Zator (2013), and Weron and Zator (2014).

${ }^{2}$ For example, in the EEX market, trading in electricity derivatives increased tenfold from a level of 119 TWh in 2002 to 1264 TWh in 2013 (EEX, 2005, 2013).
} 
period may result in a confound, showing a positive relationship with the (relative) forward price, while the true relationship is decreasing.

The paper is organized as follows. Section I summarizes Bessembinder and Lemmon (2002) and presents a revision. Section II present numerical simulations, Section III addresses a caveat concerning the way mean power demand has been operationalized in empirical tests, and section IV concludes.

\section{The Bessembinder and Lemmon (2002) Theory}

Bessembinder and Lemmon (2002) show that the electricity forward premium can be modeled as the interplay between hedging pressures by the wholesale sellers (producers) and buyers (retailers) of electricity. The forward premium is the difference between the forward price and the expected spot price: ${ }^{3}$

$$
\text { Forward Premium }=P_{F, t_{0}, t_{1}}-\mathrm{E}_{t_{0}}\left[P_{S, t_{1}}\right]
$$

In Equation (1), $t_{0}$ refers to the present period, $t_{1}$ to the future period, $P_{F, t_{0}, t_{1}}$ to the present (time $t_{0}$ ) price of a forward contract with delivery at time $t_{1}, P_{S, t_{1}}$ to the future (time $t_{1}$ ) spot price, and $\mathrm{E}_{t_{0}}[\cdot]$ to the present (time $t_{0}$ ) expectation operator for future (time $t_{1}$ ) outcomes. For ease of notation and consistency with Bessembinder and Lemmon (2002), I drop the time-indexes below.

Bessembinder and Lemmon (2002) use an equilibrium approach and assume that there is no uncertainty in spot markets, that the electricity industry is perfectly competitive, and that the time between markets is short enough to ignore the interest rate. These assumptions allow them to derive a formula showing that the forward premium depends on the distribution of electricity spot prices:

$$
P_{F}-\mathrm{E}\left[P_{S}\right]=-\frac{N_{P}}{\left(N_{P}+N_{R}\right)} \frac{R A}{c a^{x}}\left(c \bar{P}_{R} \operatorname{Cov}\left[P_{S}^{x}, P_{S}\right]-\operatorname{Cov}\left[P_{S}^{x+1}, P_{S}\right]\right)
$$

\footnotetext{
${ }^{3}$ See Weron and Zator (2014) for alternate definitions and a discussion of the confusion the interchangeable use of different definitions has caused in the literature.
} 
In Equation (2), $\bar{P}_{R}=r \cdot \mathrm{E}\left[P_{S}\right]$ refers to the regulated retail price of electricity at which retailers can sell electricity to consumers (with $r>1$, such that $\bar{P}_{R}>\mathrm{E}\left[P_{S}\right]$ ); $N_{P}$ is the number of (identical) producers; $N_{R}$ is the number of (identical) retailers; $c>2$ is a cost convexity parameter that figures in the cost function of electricity producers, $C_{i}=F+\frac{a}{c}\left(Q_{P_{i}}\right)^{c}, x=\frac{1}{c-1}<1 ; a$ is the variable cost parameter; and $R A$ is a parameter reflecting the aversion of retailers and producers to the variance of the profit.

To illustrate the implications of the underlying theory embodied in their Equation (2), Bessembinder and Lemmon (2002) run simulations by drawing demand realizations from a normal distribution with a mean varying from 75 to 125 and a standard deviation varying from 1 to 40; see Figure 1b. Bessembinder and Lemmon (2002) then use Equation (2) and their simulations to derive four hypotheses:

- Hypothesis 1: The equilibrium forward premium decreases in the anticipated variance of wholesale prices, ceteris paribus.

- $\quad$ Hypothesis 2: The equilibrium forward premium increases in the anticipated skewness of wholesale prices, ceteris paribus.

- $\quad$ Hypothesis 3: The equilibrium forward premium is convex, initially decreasing and then increasing, in the variability of power demand, ceteris paribus.

- $\quad$ Hypothesis 4: The equilibrium forward premium increases in mean power demand, ceteris paribus.

The first two hypotheses are derived from Equation (2), the latter two from numerical simulations. Hypothesis 3 is based on the simulation shown in Figure 2 (Bessembinder and Lemmon, 2002, p.1360) and Hypothesis 4 on the one shown in Figure 3 (p.1361). In the next section, I present simulation data that suggest that Hypothesis 4 should be revised as follows:

- Hypothesis 4': The equilibrium forward premium initially increases, and then decreases, in mean power demand. 


\section{Simulating the Effect of Mean Power Demand on the Forward Premium}

Bessembinder and Lemmon (2002) support Hypothesis 4 by running numerical simulations and present a graph in support of their claim; see Figure 1b. The z-axis shows the relative forward premium in percentages, $100 \% \cdot \frac{P_{F}-\mathrm{E}\left[P_{S}\right]}{\mathrm{E}\left[P_{S}\right]}$, labeled by Bessembinder and Lemmon (2002, p.1361, Figure 3) as "the bias in the forward price", as a function of the standard deviation of demand (on the $\mathrm{x}$-axis) and the mean demand (on the y-axis). For these numeric approximations, Bessembinder and Lemmon (2002) choose a strongly convex cost function with the value of the cost convexity parameter set to $c=4$ and equal numbers of retailers and producers, $N_{R}=N_{P}=20$. They set the variable cost parameter as a function of mean demand, $a=30 \frac{N_{P}{ }^{c-1}}{\bar{D}}$.

\section{Table I}

Parameters for the graphs in Figure 1

\begin{tabular}{|l|c|}
\hline \multicolumn{1}{|c|}{ Parameter } & Value \\
\hline Numbers of retailers $N R$ & 20 \\
\hline Numbers of producers $N P$ & 20 \\
\hline Convexity of demand $c$ & 4 \\
\hline Scaling parameter $a$ & $a=30 \frac{1}{100} N_{P}^{c-1}$ \\
\hline Risk aversion $R A$ & $R A=0.8 \cdot 2^{-c}=0.1$ \\
\hline Range of mean demand & $75-125$ \\
\hline Range of standard deviation & $1-40$ \\
\hline
\end{tabular}

They then calculate the relative forward premia (in percentages) for values of the mean demand between 75 and 125 and the standard deviation between 1 and 40 . To calculate the terms in Equation (2), the forward premium $P_{F}$, the expected spot price $\mathrm{E}\left[P_{S}\right]$, the mean retail price $\bar{P}_{R}$, and the covariances $\operatorname{COV}\left[P_{S}^{x}, P_{S}\right]$ and $\operatorname{COV}\left[P_{S}^{x+1}, P_{S}\right]$, Bessembinder and Lemmon (2002) use for each data point a sample of 1000 random 
draws of demand realizations from a normal distribution ${ }^{4}$ with the corresponding mean and standard deviation of demand. Table I summarizes the values of the parameters Bessembinder and Lemmon (2002) use for their graphs.

While using the same values for the graph, to increase precision, I use larger samples of demand realizations: 10,000,000 draws of demand realizations as opposed to the 1000 draws used by Bessembinder and Lemmon (2002). ${ }^{5}$ I calculate the terms in Equation (2) for each integer value of the mean and the standard deviation of demand, resulting in a high grid resolution of $51 \times 40$ (=2040 data points).

Figure 1a shows my graph next to Bessembinder and Lemmon's (2002) graph in Figure $1 \mathrm{~b}$. The shapes are very similar, but the axis of mean demand is numbered in my graph in a direction opposite to the one in the graph by Bessembinder and Lemmon (2002). With a movement (in the North-East direction) along the axis of mean demand, the value decreases in my graph, but increases in Bessembinder and Lemmon's (2002) graph. The effect of increasing mean demand on equilibrium relative forward premia found in this analysis, depicted in Figure 1a, is thus opposite to the effect found in Bessembinder and Lemmon (2002), depicted in Figure 1b. It seems clear that the graph in Bessembinder and Lemmon (2002) is not correct. ${ }^{6}$

\footnotetext{
${ }^{4}$ In the simulations the distribution must be truncated at zero to avoid solutions with complex numbers due to realizations of negative demand. The distortive effect of the truncation should be negligible when the average demand is high relative to the standard deviation of demand.

${ }^{5}$ This level of precision, 10,000,000 draws of demand realizations, is used for all reported figures in this paper, unless indicated otherwise.

${ }^{6}$ The simulation program in Mathematica for all the graphs in the paper can be downloaded from https://sites.google.com/site/slvstrnl/Home/papers/forward-premia-in-electricity-markets, except for the simulation program used to generate the graphs in Bessembinder and Lemmon (2002), which is lost. The downloads include an alternate simulation in Matlab written by Marek Zelenay, who, independently and unwittingly of my analyses and results, also wrote a simulation program to reproduce (or refute) Figure 3 in Bessembinder and Lemmon (2002). His results are identical to mine. Figure 2 in Bessembinder and Lemmon (2002, p.1360) shows the relative forward premium against the demand standard deviation (on the $\mathrm{x}$-axis) and the cost convexity parameter $c$ (on the y-axis). However, my simulations indicate that this figure is a graph of the forward premium (as opposed to the relative forward premium). The figures have, however, broadly the same shapes and Hypothesis 3 thus remains valid.
} 


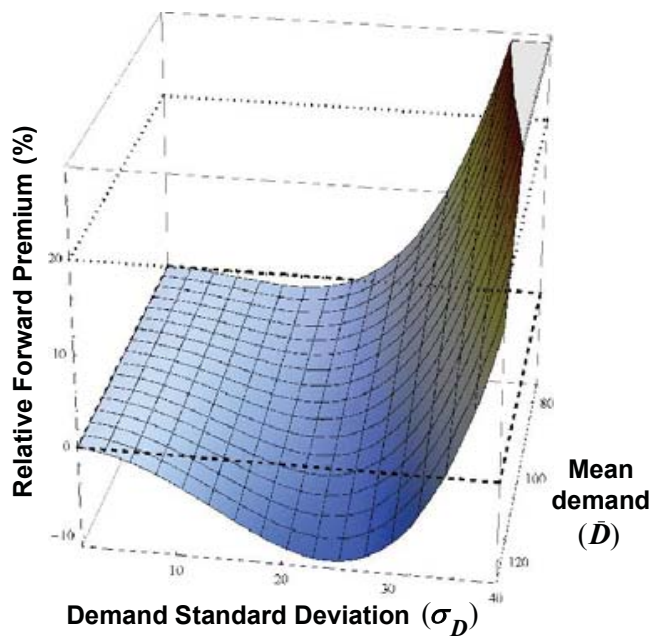

a) Graph based on my simulations using a sample size of 10,000,000 draws for each data point.

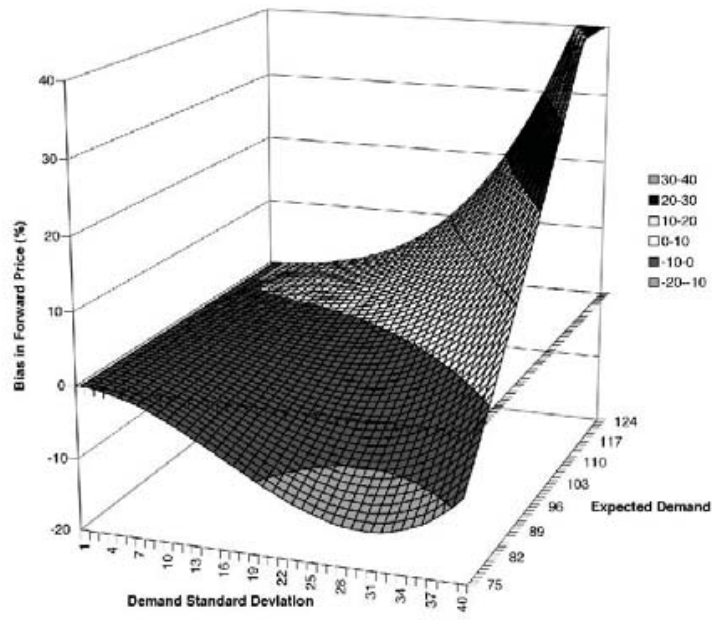

b) Graph reproduced from Bessembinder and Lemmon (2002, Figure 3, p.1361). They report using a sample size of 1000 draws for each data point. The grid resolution is unknown.

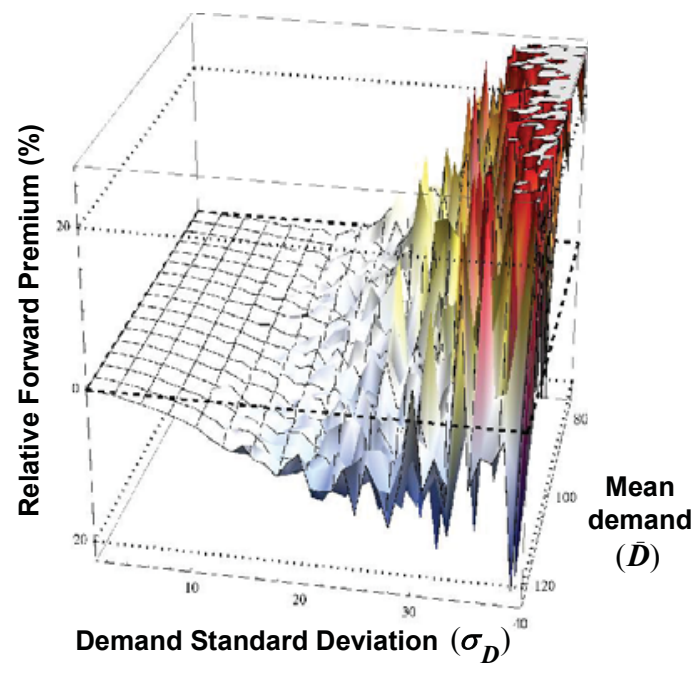

c) Graph based on my simulations using a sample size of 1000 draws for each data point.

Figure 1. The relative forward premium as a function of mean demand and demand standard deviation

The graphs show the relative forward premium in percentages as a function of the mean demand and the demand standard deviation. The graphs in a) and c) are created by my simulations, while the graph in b) was created by Bessembinder and Lemmon (2002, Figure 3, p.1361). The graphs in a) and c) have a grid resolution of 51x40.The grid resolution of the graph in b) is unknown. 
The relative forward premium in percentages,

$$
100 \% \cdot \frac{P_{F}-\mathrm{E}\left[P_{S}\right]}{\mathrm{E}\left[P_{S}\right]}
$$

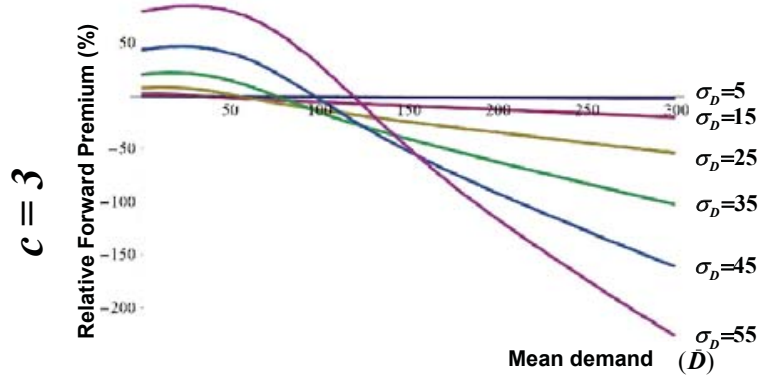

a)

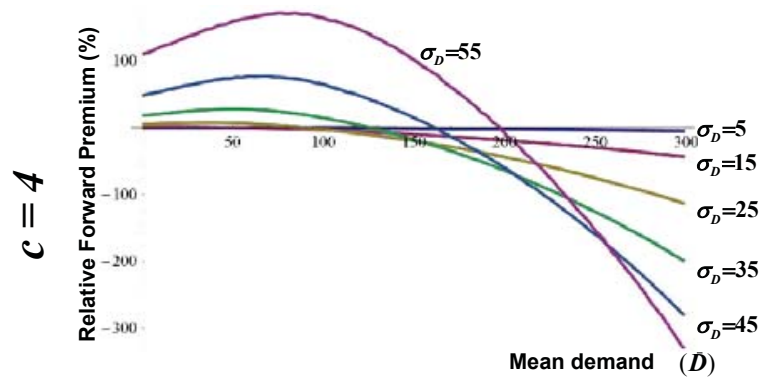

c)

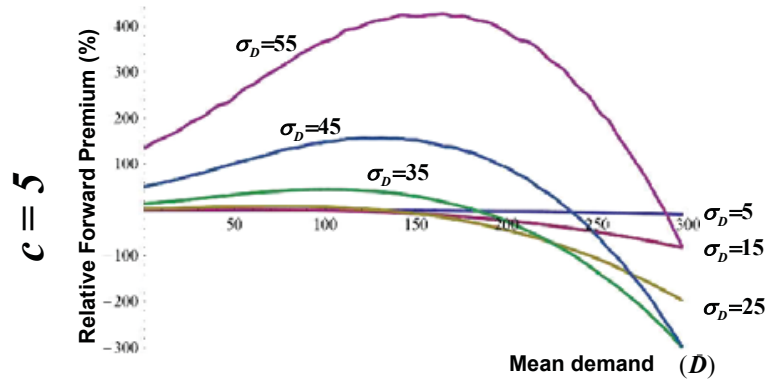

e)
The forward premium, $P_{F}-\mathrm{E}\left[P_{S}\right]$

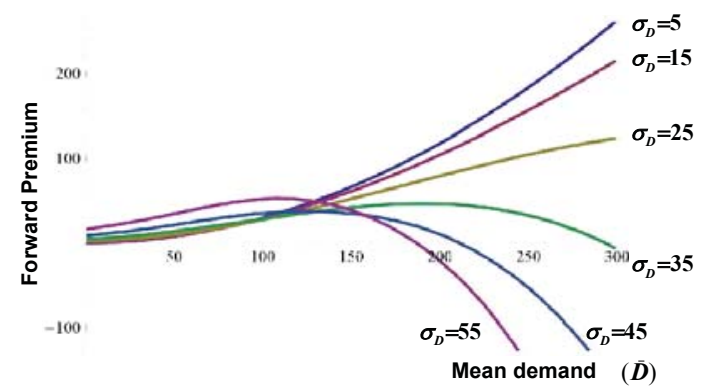

b)

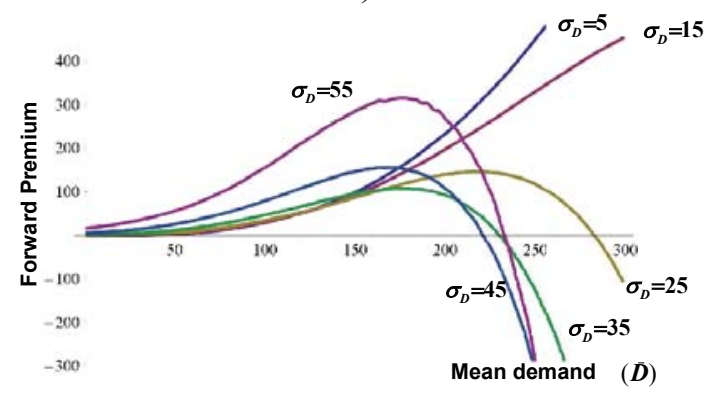

d)

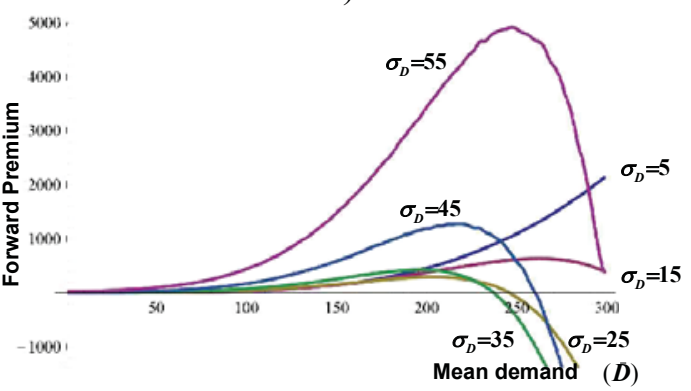

f)

Figure 2. The (relative) forward premium for different values of the cost convexity parameter

The graphs show the relative forward premium in percentages (left-hand side) and the forward premium (right-hand side) as a function of the mean demand for different values of the demand standard deviation and the cost convexity parameter. The lefthand column indicates the value of the convexity cost parameter $\mathrm{c}$. The graphs are created by calculating the (relative) forward premium for 100 values of the mean demand and connecting the resulting points. 


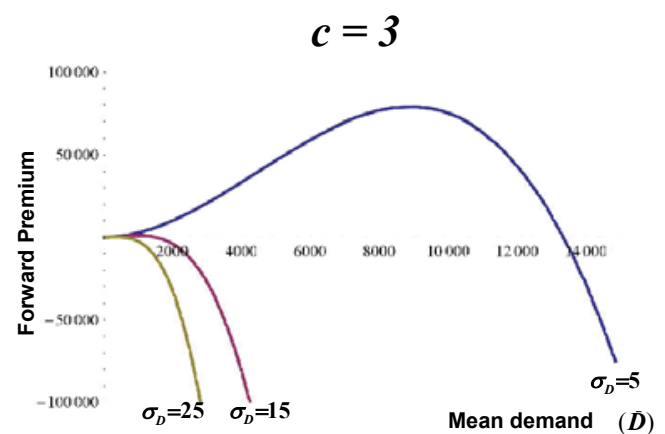

a)

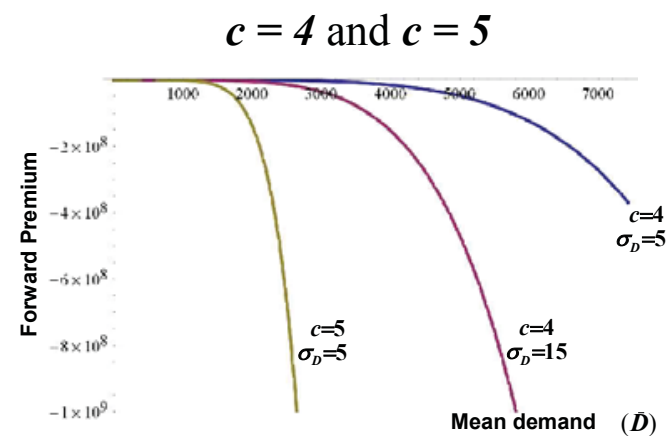

b)

Figure 3. The forward premium when the standard deviation is low

The graphs show the forward premium as a function of the mean demand for different values of the demand standard deviation and the cost convexity parameter. The graphs focus on the curves that increased over the range of values for the mean demand used in Figure 2, but use an extended range. The graphs show that when the range is extended, the forward premium eventually decreases in the mean demand. The graphs are created by calculating the (relative) forward premium for 100 values of the mean demand and connecting the resulting points.

To test if the number of samples of demand realizations could cause a difference, I run the same simulation sampling 1000 demand realizations and show the results in Figure 1c, which shows that the values for the forward premium computed on the basis of a sample of a 1000 demand realizations still have a remarkably high margin of error. The resulting graph, while broadly having the same shape as the graphs in Figure 1a and $1 \mathrm{~b}$, is therefore not smooth.

For a better understanding of the effect of the mean demand on the forward premium, I create, in Figure 2, two-dimensional graphs of both the relative forward premium in percentages, $100 \% \cdot \frac{P_{F}-\mathrm{E}\left[P_{S}\right]}{\mathrm{E}\left[P_{S}\right]}$, (on the left-hand side) and the forward premium, $P_{F}-\mathrm{E}\left[P_{S}\right]$, (on the right-hand side) as a function of the mean demand over a range from 1 to 300 for different values of the demand standard deviation and the convexity cost parameter $c$. Note that over the range used for the values of the mean demand, the relative forward premium first increases, and then decreases, for all depicted values of the demand standard deviation and the convexity cost parameter. The forward premium also first increases, and then decreases for most depicted values of the demand standard deviation and the convexity cost parameter. For the lower 
values of demand standard deviation, especially when the convexity cost parameter is low, the forward premium increases over the range depicted. However, as Figure 3 shows, also these graphs eventually decrease when the range is sufficiently extended. ${ }^{7}$ These simulations thus suggest that the theory of Bessembinder and Lemmon (2002) implies that the relationship between the mean demand and the forward premium is best characterized by the revised Hypothesis 4':

Hypothesis 4': The equilibrium forward premium and the relative forward premium initially increase, and then decrease, in mean power demand, ceteris paribus.

\section{Empirical Tests}

Several studies have tested for the effect of mean power demand on the forward premium (Bessembinder and Lemmon, 2002; Karakatsani and Bunn, 2005; Lucia and Torro, 2008; Furio and Meneu, 2009; Handika and Trück, 2013). All find support for the original hypothesis that the forward premium increases in mean power demand. This may indicate that the power markets under investigation were best characterized by the lower plot-ranges in Figure $2 b, 2 d$, or $2 f$, where the forward premium is still increasing in mean power demand. However, for these ranges the relative forward premium may have been decreasing in mean power, a thesis that was not checked in these papers.

An important caveat for these studies is that they employed an empirical strategy in which the mean power demand is calculated as a monthly average. The mean power demand as defined in Bessembinder and Lemmon (2002) is, however, a more long-term variable. As the retail price directly follows from the mean power demand by $\bar{P}_{R}=r \cdot \mathrm{E}\left[P_{S}\right]=r \cdot \mathrm{E}\left[C^{\prime}\left[\frac{D}{N_{P}}\right]\right]$, the period for which the retail price is fixed is equal to the period over which the mean power demand is calculated. Mean power demand, as defined in Bessembinder and Lemmon (2002), must thus be calculated over the same period as the period for which retail prices are fixed. In most markets, the retail price is

\footnotetext{
${ }^{7}$ The graphs show that, to capture the eventual decrease of the forward premium, the range for the values of mean demand may have to be extended considerably for low values of the cost convexity parameter $c$ and the demand standard deviation. When the demand standard deviation was $\sigma_{D}=5$, I needed to extend the range to 15,000 for $c=3$ and to 7500 for $c=4$.
} 
set for periods such as six months up to three years (Borenstein, 2005; Gardner, 2010). Calculating the mean power demand as a more short-term average may result in confounds.

Suppose, for example, that in a regional or national market the retail rate is fixed for a year. The mean power demand must thus be calculated over a year and the retail rate is set as $\bar{P}_{R}=r \cdot \mathrm{E}\left[P_{S}\right]=r \cdot \mathrm{E}\left[C^{\prime}\left[\frac{D}{N_{P}}\right]\right]$. To elaborate the example, suppose that the yearly mean power demand is 100 , the monthly mean power demand is 90 in half of the year and 110 in the other half, and the standard deviation of power demand is 35 . Moreover, the mean power demand grows by $1 \%$ and we collect 20 years (and thus 240 months) of data. As can be seen in Figure 2c, this implies that the relative forward premium should be decreasing in the mean power demand. I run a simulation using the parameters of our example and run the regression $r F P=a+b_{1} \cdot$ Skew $+b_{2} \cdot \operatorname{Var}+b_{3} \cdot \bar{D}_{\text {Monthly }}+b_{4} \cdot \bar{D}_{\text {Yearly }}$, where Skew is the skewness, Var the variance, $\bar{D}_{\text {Monthly }}$ the mean monthly power demand and $\bar{D}_{\text {Yearly }}$ the mean yearly power demand.

\section{Table II}

Parameters for the graphs in Figure 1

\begin{tabular}{lccc}
\hline & $(1)$ & $(2)$ & $(3)$ \\
VARIABLES & rFPr & rFPr & rFPpr \\
\hline \multirow{3}{*}{ Skewpr } & $8.86^{* * *}$ & $-1.02^{* * *}$ & $0.29 * * *$ \\
& $(1.11)$ & $(0.04)$ & $(0.06)$ \\
Varpr & $-0.00^{* * *}$ & $0.00^{* * *}$ & $0.00^{* * *}$ \\
& $(0.00)$ & $(0.00)$ & $(0.00)$ \\
MDempr & $0.23^{* * *}$ & & $0.03^{* * *}$ \\
& $(0.03)$ & & $(0.00)$ \\
YDempr & & $-0.05^{* * *}$ & $-0.05^{* * *}$ \\
& & $(0.00)$ & $(0.00)$ \\
Constant & $-38.66^{* * *}$ & $6.82^{* * *}$ & $1.09^{* * *}$ \\
& $(4.54)$ & $(0.09)$ & $(0.23)$ \\
& & & \\
Observations & 240 & 240 & 240 \\
R-squared & 0.74 & 1.00 & 1.00 \\
\hline \multicolumn{4}{c}{ Standard errors in parentheses } \\
& $* * * \mathrm{p}<0.01, * * \mathrm{p}<0.05, * \mathrm{p}<0.1$ &
\end{tabular}

Table II shows the regressions, in which Model (1) only includes the mean monthly power demand, Model (2) only the mean yearly power demand, and Model (3) 
both variables. $^{8}$

Model (1) shows that when only the mean monthly power demand is included, a positive relationship is obtained, while Model (2) and (3) show that the mean yearly power demand results in a negative relationship. As the retail price is calculated as a markup on the yearly mean price, the mean power demand as used in Bessembinder and Lemmon (2002) is calculated as a yearly average and the relative forward premium is decreasing in the mean power demand, as shown in Figure 2c.

In Model (3), where both the monthly and the yearly mean power demand variables are included, the monthly measure captures the effect of deviations of the monthly mean from the yearly mean. If the power demand in one month is high relative to the yearly average, this indicates high prices relative to the fixed retail rate and thus a higher risk for retailers. As a result, retailers want to hedge more to avoid the risk and thus exert upwards pressure on the forward premium. In contrast, if the yearly mean demand increases, the retail price increases appropriately, partially ameliorating the risk of higher prices, and thus exerting less upwards pressure on the forward premium. After taking the downwards pressure stemming from producers wishing to hedge their risk into account, the net effect of an increase in yearly mean demand is negative.

Empirical tests by Bessembinder and Lemmon (2002) thus cannot simply use monthly averages of power demand as proxies for the mean power demand, but should average power demand over the same period as that for which the retail rate is supposed to be fixed.

\section{Conclusion}

Bessembinder and Lemmon (2002), using a risk premium theory by linking the forward electricity price to the expected spot electricity price, hypothesize that the equilibrium forward premium increases in mean power demand. This paper adds two caveats regarding the applications and tests of Bessembinder and Lemmon (2002). Firstly, numerical simulations of the relative forward premium indicate that Figure 3 in

\footnotetext{
${ }^{8}$ The regression is based on the true values of the variables. They have thus been calculated using a large sample (250.000). Using a smaller sample (30) instead, as will be the case in empirical studies, does not change the relationships reported in the regression, though sample effects, naturally, occasionally affect the outcomes somewhat.
} 
Bessembinder and Lemmon (2002, p.1361), which forms the basis for this hypothesis, is not correct in the sense that it does not follow from the theoretical model. Numerical simulations suggest that that the hypothesis should be revised as follows: "The equilibrium forward premium and relative forward premium initially increase, and then decrease, in mean power demand, ceteris paribus.". Secondly, empirical tests should use a definition of the mean power demand in line with Bessembinder and Lemmon (2002) to avoid confounds. Specifically, the mean power demand should be averaged over the same period as that for which the retail rate is supposed to be fixed.

\section{REFERENCES}

Bessembinder, Hendrik, and Michael L. Lemmon, 2002, Equilibrium pricing and optimal hedging in electricity forward markets, Journal of Finance 57, 13471382.

Botterud, Audun, Tarjei Kristiansen, and Marija D. Ilic, 2010, The relationship between spot and futures prices in the Nord Pool electricity market, Energy Economics 32, 967-978.

Bunn, Derek W., and Dipeng Chen, 2013. The forward premium in electricity futures. Journal of Empirical Finance 23, 173-186.

Daskalakis, George, and Raphael N. Markellos, R. N., 2009, Are electricity risk premia affected by emission allowance prices? Evidence from the EEX, Nord Pool and Powernext, Energy Policy 37, 2594-2604.

Diko, Pavel, Steve Lawford, and Valerie Limpens, 2006, Risk premia in electricity forward prices, Studies in Nonlinear Dynamics \& Econometrics 10, Article 7.

Douglas, Stratford, and Julia Popova, 2008, Storage and the electricity forward premium, Energy Economics 30, 1712-1727.

EEX 2005, Annual Report 2005. Available at https://www.eex.com/en/about/eex/annual-report.

EEX 2013, Annual Report 2013. Available at https://www.eex.com/en/about/eex/annual-report. 
Furio, Dolores, and Vicente Meneu, 2010, Expectations and forward risk premium in the Spanish deregulated power market, Energy Policy, 38, 784-793.

Hadsell, Lester, and Hany A. Shawky, 2006, Electricity price volatility and the marginal cost of congestion: An empirical study of peak hours on the NYISO market, 2001-2004, The Energy Journal 27, 157-179.

Handika, Rangga, and Stefan Trueck, 2013, Risk Premiums in interconnected Australian electricity futures markets. SSRN Working Paper. Available at http://dx.doi.org/10.2139/ssrn.2279945.

Haugom, Erik, and Carl J. Ullrich, 2012, Market efficiency and risk premia in shortterm forward prices, Energy Economics 34, 1931-1941.

Karakatsani, Nektaria V., and Derek W. Bunn, 2005, Diurnal reversals of electricity forward premia. London Business School Research Paper.

Longstaff, Francis A., and Ashley W. Wang, 2004, Electricity forward prices: a highfrequency empirical analysis, Journal of Finance 59, 1877-1900.

Lucia, Julio, and Hipolit Torro, 2008, Short-term electricity futures prices: Evidence on the time-varying risk premium. Working Paper Series EC 2008-08. Available at http://papers.ssrn.com/sol3/papers.cfm?abstract_id=1014035.

Redl, Christian, and Derek W. Bunn, 2013, Determinants of the premium in forward contracts, Journal of Regulatory Economics 43, 90-111.

Redl, Christian, Reinhard Haas, Claus Huber, and Bernhard Böhm, 2009, Price formation in electricity forward markets and the relevance of systematic forecast errors, Energy Economics 31, 356-364.

Weron, R., 2006, Modeling and forecasting electricity loads and prices: A statistical approach. HSC Books.

Weron, Rafal, 2008, Market price of risk implied by Asian-style electricity options and futures. Energy Economics 30, 1098-1115.

Weron, Rafal and Michal Zator, 2014, Revisiting the relationship between spot and futures prices in the Nord Pool electricity market, Energy Economics 44, 178-190.

Zator, Michal, 2013, Relationship between spot and futures prices in electricity markets: Pitfalls of regression analysis. HSC Research Reports HSC/13/06, Hugo Steinhaus Center, Wroclaw University of Technology. 


\section{Working Paper Series}

ISSN 1211-3298

Registration No. (Ministry of Culture): E 19443

Individual researchers, as well as the on-line and printed versions of the CERGE-EI Working Papers (including their dissemination) were supported from institutional support RVO 67985998 from Economics Institute of the ASCR, v. v. i.

Specific research support and/or other grants the researchers/publications benefited from are acknowledged at the beginning of the Paper.

(c) Silvester van Koten, 2015

All rights reserved. No part of this publication may be reproduced, stored in a retrieval system or transmitted in any form or by any means, electronic, mechanical or photocopying, recording, or otherwise without the prior permission of the publisher.

Published by

Charles University in Prague, Center for Economic Research and Graduate Education (CERGE) and

Economics Institute of the ASCR, v. v. i. (EI)

CERGE-El, Politických vězňů 7, 11121 Prague 1, tel.: +420 224005 153, Czech Republic.

Printed by CERGE-EI, Prague

Subscription: CERGE-EI homepage: http://www.cerge-ei.cz

Phone: + 420224005153

Email: office@cerge-ei.cz

Web: http://www.cerge-ei.cz

Editor: Marek Kapička

The paper is available online at http://www.cerge-ei.cz/publications/working_papers/.

ISBN 978-80-7343-348-2 (Univerzita Karlova. Centrum pro ekonomický výzkum a doktorské studium)

ISBN 978-80-7344-340-5 (Akademie věd České republiky. Národohospodářský ústav) 
CERGE-EI

P.O.BOX 882

Politických vězňů 7

11121 Praha 1

Czech Republic http://www.cerge-ei.cz 